\title{
Flood Frequency Analysis of a Sub-watershed in Meenachil River Basin Using Gumbels Extreme Value Distribution
}

\author{
Riyola George ${ }^{1 *}$ and Asha Joseph ${ }^{2}$ \\ ${ }^{1}$ Department of Soil and Water Engineering, ${ }^{2}$ Department of Irrigation and Drainage \\ Engineering, Kelappaji College of Agricultural Engineering and Technology, \\ Kerala Agricultural University (KAU), Malappuram-679573, Kerala, India
}

*Corresponding author

\section{A B S T R A C T}

\section{Keywords}

Gumbels

distribution, Flood

frequency analysis,

Goodness of fit,

Meenachil River,

Return period, Peak

discharge

\section{Article Info}

Accepted:

26 May 2020

Available Online:

10 June 2020
The extreme flood events are always a chapter of concern in all river basins, accompanied by loss of property, lives and economics. Estimation of flood peak discharge for a desired return period is pre-requisite for river basin management, design and execution of structures like bridges, culverts, dams, etc. Hence flood frequency analysis is essential to predict the flood peaks of different return periods. The Gumbels extreme value distribution is one of the best probability distribution model used to model annual maximum flood discharge. This paper presents the results of the flood frequency analysis of Meenachil river basin in Kerala using Gumbels extreme value distribution. The analysis used 34 years of data (1985-2018) to model the annual maximum discharge. The flood peak values of return period 2, 10, 50 and 100 year were computed and further extrapolation could be done to find out the flood discharge of any return period. The $\mathrm{R}^{2}$ values of the plots of return period versus stream flow and reduced variate versus flood peak showed that the Gumbels extreme value distribution is suitable for predicting the expected flood flow in Meenachil River.

\section{Introduction}

Flood is one of the devastating natural disasters which occur in India every year during the south west monsoon season. In planning and design of water resources projects, it is very important to determine the magnitude and frequency of flood that will occur in the project area. Flood frequency analysis is the method of fitting a probability model to annual flood peak data recorded over a period of observation at a catchment outlet. The model parameters thus established can then be used to predict the flood peaks of desired return period.

Gumbels extreme value distribution is a reliable method to estimate the annual maximum flood peaks which is essential for flood plain management and design and 
location of hydraulic structures. Flood mitigation and risk management using both structural (obtained by river training, storage dams, weirs, etc.) and/or non-structural (obtained by forecasting and rescue operations) measures are important aspect regarding occurrence of flood (Solomon and Prince, 2013).

Estimation of flood return periods associated with flood peaks of different magnitudes from recorded historical floods using statistical techniques specially enhance the flood rescue operation (Mujiburrehman, 2015). There is no statistical distribution that has gained worldwide acceptance and is specific to a particular country (Nirman, 2017).

Even then, in order to ensure safety and economic hydrologic design in the catchment area, the Gumbel extreme value distribution which is commonly used for flood frequency analysis is selected for this study.

Meenachil River face the threat of wide spread illegal sand mining. Previously the banks of the river were very much enriched with sands. Now the banks of the river are filled with grasses and mud. The depth of river is increasing day by day due to this illegal sand mining.

The sewage pollution is also another menace of the river. This river is not exceptional to annual floods during monsoon and causing destruction to the public. Meenachil River is highly dangerous and wild during flood season due to the depth of river.

This river contributed vigorously to 2018 Kerala flood and major causality in the human history. In view of all the above facts a flood frequency analysis was carried out to find out the likely flow discharge to be expected in the river at various return periods based on observed stream flow data.

\section{Details of the study area}

Meenachil River located in Kottayam district of Kerala acts as a cradle for the development of culture for Travancore. The river experiences enormous impacts of losses in terms of both property and life during monsoon flood. Due to changes caused by urbanization, the stream flow record of Meenachil river basin in the humid tropical zone of Kerala State is remarkably changed.

These alterations in stream flow scenario was more specifically, an indicator of upstreamarena urbanization in a humid tropical river basin (Celine et al., 2012). Watersheds in Meenachil basin are parts of Western Ghats, which is categorised into ecologically sensitive region (Vincy et al., 2012). Meenachil River basin consists of 47 subwatersheds and 114 micro watersheds.

The river finally drains into Vembanad Lake. The Pala sub-watershed which contributes a lot to the Kerala economy, situated at the upstream portion of Meenachil River basin is selected for the present study. The basin map of study area is shown in Fig. 1. The sub watershed lies between $9^{\circ} 38^{\prime} 56.89^{\prime \prime} \mathrm{N}$ and $9^{\circ} 49^{\prime} 50.64^{\prime \prime} \mathrm{N}$ latitude, and 76 36'57.57"E and 76 56'17.99"E longitude. The watershed covers an area of $444.115 \mathrm{Km}^{2}$ which is approximately 35 per cent of the total area of Meenachil river basin (about $1272 \mathrm{Km}^{2}$ of drainage area).

\section{Materials and Methods}

\section{Data collection}

The daily discharge data observed at Pala gauging station $\left(76^{\circ} 41^{\prime} 2.40^{\prime \prime} \mathrm{E}, 9^{\circ} 42^{\prime} 36^{\prime \prime} \mathrm{N}\right)$ of Meenachil river basin for a period of 34 years from 1985 to 2018 was collected from the Irrigation Design and Research Board (IDRB) Trivandrum, Department of Irrigation, Kerala. 
The annual maximum discharge data were used for flood frequency analysis.

\section{Data analysis}

Flow data are denoted in terms of exceedance probabilities and recurrence intervals. Considering, $Q_{i}$ as the annual maximum flood in year $i$ and the quantile $Q_{i}(\mathrm{~F})$ as the value of

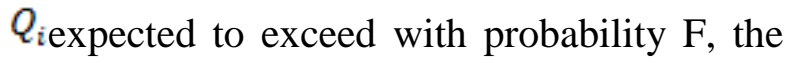
following relation, $\mathrm{P}\left(Q_{i} \geq Q_{i}(\mathrm{~F})\right)=\mathrm{F}$, during the year of concern is derived. Thus, there is an $\mathrm{F} \%$ chance for $\mathrm{Q} \geq \mathrm{Q}(\mathrm{F})$ occurrence. In other way, there is a $(1-\mathrm{F}) \%$ chance that events $\mathrm{X}<\mathrm{Q}(\mathrm{F})$ occurs. The return period $\mathrm{T}$ of a flood, is the reciprocal of the probability of exceedance in one year computed as $1 /(\mathrm{F})$ (Haan, 1977; Mujere, 2011).

\section{Gumbels distribution}

Gumbel distribution also known as Generalized Extreme Value distribution Type-I is a statistical technique, generally used for predicting extreme hydrological events and climate variables (Zelenhasic, 1970; Haan, 1977; Shaw, 1983). The study adopted this model for flood frequency analysis due to following reasons: (1) peak flow data are homogeneous and independent hence lack long-term trends; (2) the river is less regulated, hence is not significantly affected by reservoir operations and diversions; and (3) flow data cover a relatively long record and is of good quality (Mujere, 2011; Mukherjee, 2013).

Gumbel distribution uses the following equation for fitting the observed series of flood flows at different return periods $\mathrm{T}$ (Chow, 1988; Chow, 1964; Beard, 1943):

$x_{T}=\bar{x}+K \sigma_{n-1}$

Where, ${ }^{x_{T}}$ represents the magnitude of flood event at $\mathrm{T}$ return period; $\mathrm{K}$ represents the frequency factor; ${ }^{\bar{x}}$ represents the mean of the maximum instantaneous discharge; $\sigma_{n-1}$ represents the standard deviation of the maximum instantaneous discharge.

The reduced variate is related as $y_{T}=-$ $\left[\ln . \ln \frac{T}{T-1}\right]$. Frequency factor is denoted as $k=\frac{y_{T}-\overline{y_{n n}}}{s_{n}}, \quad$ where, $\quad \overline{y_{n}}=0.5396$ and $S_{n}=1.1255$ are selected suitably from standard table (Subramanya, 2004).

\section{Results and Discussion}

The analysis of procured data using Gumbel's distribution was performed using the above relations and the results are shown in Table 1. The flood frequency curve, i.e., a graph of discharge versus return period, was depicted in Fig. 2. A graph of reduced variate versus flood peak was plotted for upper Meenachil River Basin, which is represented in Fig. 3.

The maximum instantaneous discharge of $894.09 \mathrm{~m}^{3} / \mathrm{s}$ was recorded in 2018 during which Kerala faced a devastating flood while the lowest discharge of $139.28 \mathrm{~m}^{3} / \mathrm{s}$ was recorded in 2012 which was the driest year. The 34-year mean instantaneous discharge value was found as $357.63 \mathrm{~m}^{3} / \mathrm{s}$. In addition, the flood frequency curve resulted in $\mathrm{R}^{2}$ value of 0.967 , which is an acceptable value.

Gumbel's distribution was also used to compute the flood magnitude corresponding to different recurrence intervals $\mathrm{T}$ as shown in Table 2. Chi-square $(\chi 2)$ test was performed to find the goodness of fit between the observed and predicted discharge values. The test revealed a satisfactory fit between observed and predicted flood flow values that enabled prediction of flood frequency using Gumbel distribution. 
Table.1 Computation table of Gumbels distribution

\begin{tabular}{|c|c|c|c|c|c|}
\hline Year & $\begin{array}{l}\text { Peak flood } \\
\left(\mathbf{m}^{3} / \mathbf{s}\right)\end{array}$ & $\begin{array}{c}\text { Peak flood in } \\
\text { descending order } \\
\left(\mathrm{m}^{3} / \mathrm{s}\right)\end{array}$ & Rank (m) & $\begin{array}{l}\text { Return } \\
\text { period } \\
T=\frac{n+1}{m}\end{array}$ & $\begin{array}{l}\text { Reduced variate } \\
y_{T}=-\left[\ln \cdot \ln \frac{T}{T-1}\right]\end{array}$ \\
\hline 1985 & 616.6300049 & 894.0943453 & 1 & 35 & 3.540889304 \\
\hline 1986 & 614.47 & 649.4799805 & 2 & 17.5 & 2.832924885 \\
\hline 1987 & 430.980011 & 616.6300049 & 3 & 11.66666667 & 2.412264269 \\
\hline 1988 & 414.9700012 & 614.47 & 4 & 8.75 & 2.108986882 \\
\hline 1989 & 649.4799805 & 535.0900269 & 5 & 7 & 1.869824714 \\
\hline 1990 & 307.4700012 & 525.41 & 6 & 5.833333333 & 1.671035528 \\
\hline 1991 & 296.7900085 & 458 & 7 & 5 & 1.499939987 \\
\hline 1992 & 383.0299988 & 447.58 & 8 & 4.375 & 1.348955435 \\
\hline 1993 & 277.7600098 & 440.6532898 & 9 & 3.888888889 & 1.213176618 \\
\hline 1994 & 525.41 & 430.980011 & 10 & 3.5 & 1.08923964 \\
\hline 1995 & 458 & 414.9700012 & 11 & 3.181818182 & 0.974729942 \\
\hline 1996 & 340.18 & 413.9700012 & 12 & 2.916666667 & 0.867848615 \\
\hline 1997 & 305.91 & 406.25 & 13 & 2.692307692 & 0.767212305 \\
\hline 1998 & 447.58 & 383.0299988 & 14 & 2.5 & 0.671726992 \\
\hline 1999 & 268.0299988 & 348.1199951 & 15 & 2.333333333 & 0.580504824 \\
\hline 2000 & 272.6700134 & 342.0799866 & 16 & 2.1875 & 0.492807132 \\
\hline 2001 & 535.0900269 & 340.18 & 17 & 2.058823529 & 0.408003873 \\
\hline 2002 & 163.9199982 & 327.25 & 18 & 1.944444444 & 0.325543568 \\
\hline 2003 & 148.9499969 & 307.4700012 & 19 & 1.842105263 & 0.244929988 \\
\hline 2004 & 201.9100037 & 305.91 & 20 & 1.75 & 0.165702981 \\
\hline 2005 & 342.0799866 & 296.7900085 & 21 & 1.666666667 & 0.087421572 \\
\hline 2006 & 224.1399994 & 295.730011 & 22 & 1.590909091 & 0.009647686 \\
\hline 2007 & 295.730011 & 277.7600098 & 23 & 1.52173913 & -0.068071098 \\
\hline 2008 & 163.0500031 & 272.6700134 & 24 & 1.458333333 & -0.146221719 \\
\hline 2009 & 205.9600067 & 268.0299988 & 25 & 1.4 & -0.225351487 \\
\hline 2010 & 348.1199951 & 224.1399994 & 26 & 1.346153846 & -0.306103956 \\
\hline 2011 & 413.9700012 & 205.9600067 & 27 & 1.296296296 & -0.389272391 \\
\hline 2012 & 139.2799988 & 201.9100037 & 28 & 1.25 & -0.475884995 \\
\hline 2013 & 158.5299988 & 163.9199982 & 29 & 1.206896552 & -0.567350706 \\
\hline 2014 & 406.25 & 163.0500031 & 30 & 1.166666667 & -0.665729811 \\
\hline 2015 & 327.25 & 158.5299988 & 31 & 1.129032258 & -0.77429099 \\
\hline 2016 & 141.1078644 & 148.9499969 & 32 & 1.09375 & -0.898833547 \\
\hline 2017 & 440.6532898 & 141.1078644 & 33 & 1.060606061 & -1.051590868 \\
\hline 2018 & 894.0943453 & 139.2799988 & 34 & 1.029411765 & -1.268452966 \\
\hline $\begin{array}{c}\text { Sum } \\
\text { Average }\end{array}$ & & $\begin{array}{l}12159.45 \\
357.6308\end{array}$ & & & \\
\hline
\end{tabular}


Table.2 Calculation of expected flood in Meenachil River

\begin{tabular}{|c|c|c|c|}
\hline $\begin{array}{c}\text { Return period T } \\
\text { in years }\end{array}$ & $\left.\begin{array}{c}\text { Reduced variate } \\
\boldsymbol{y}_{\boldsymbol{T}}=-\left[\ln \cdot \ln \frac{\boldsymbol{T}}{\boldsymbol{T}-\mathbf{1}}\right]\end{array}\right]$ & $\begin{array}{c}\text { Frequency factor } \\
\boldsymbol{k}=\left(\boldsymbol{y}_{\boldsymbol{T}}-\overline{\boldsymbol{y}_{\boldsymbol{n}}}\right) / \boldsymbol{s}_{\boldsymbol{n}}\end{array}$ & $\begin{array}{c}\text { Expected flood } \\
\boldsymbol{x}_{\boldsymbol{T}}=\overline{\boldsymbol{x}}+\boldsymbol{K} \boldsymbol{\sigma}_{\boldsymbol{n}-\mathbf{1}}\end{array}$ \\
\hline $\mathbf{2}$ & 0.366512921 & 0.153786832 & 331.41 \\
\hline $\mathbf{1 0}$ & 2.250367327 & 1.52000651 & 616.84 \\
\hline $\mathbf{5 0}$ & 3.901938658 & 2.987417733 & 867.08 \\
\hline $\mathbf{1 0 0}$ & 4.600149227 & 3.607773636 & 972.87 \\
\hline
\end{tabular}

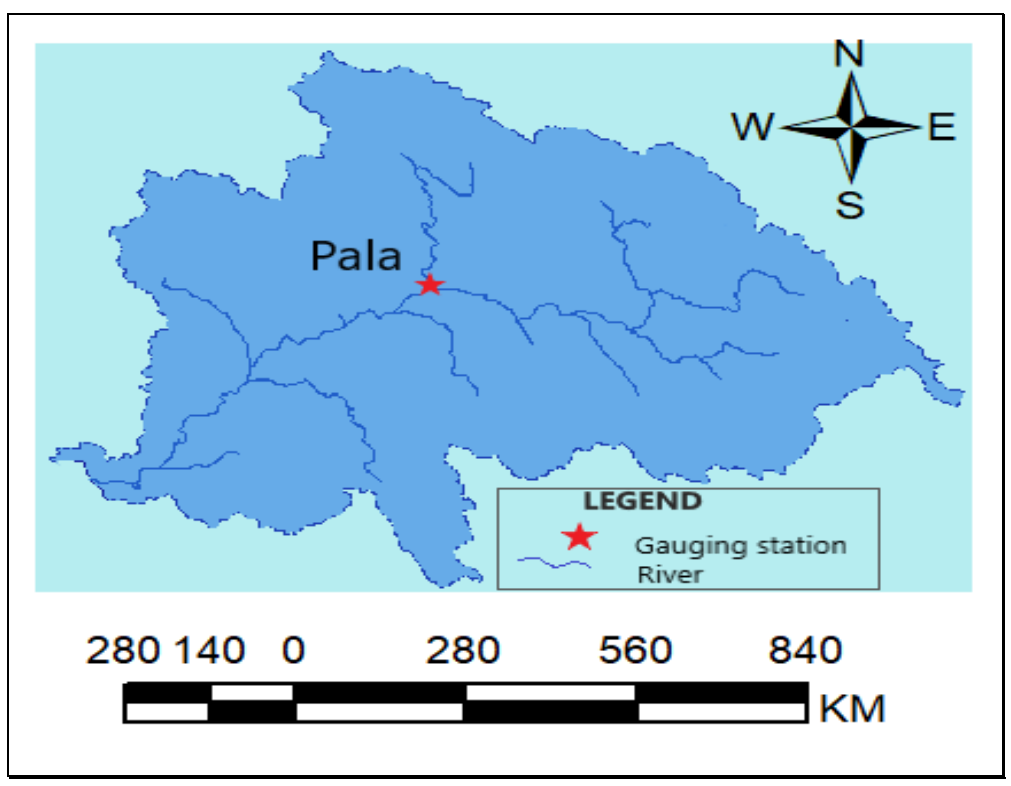

Fig.1 Location of study area (Meenachil River Basin, Kerala)

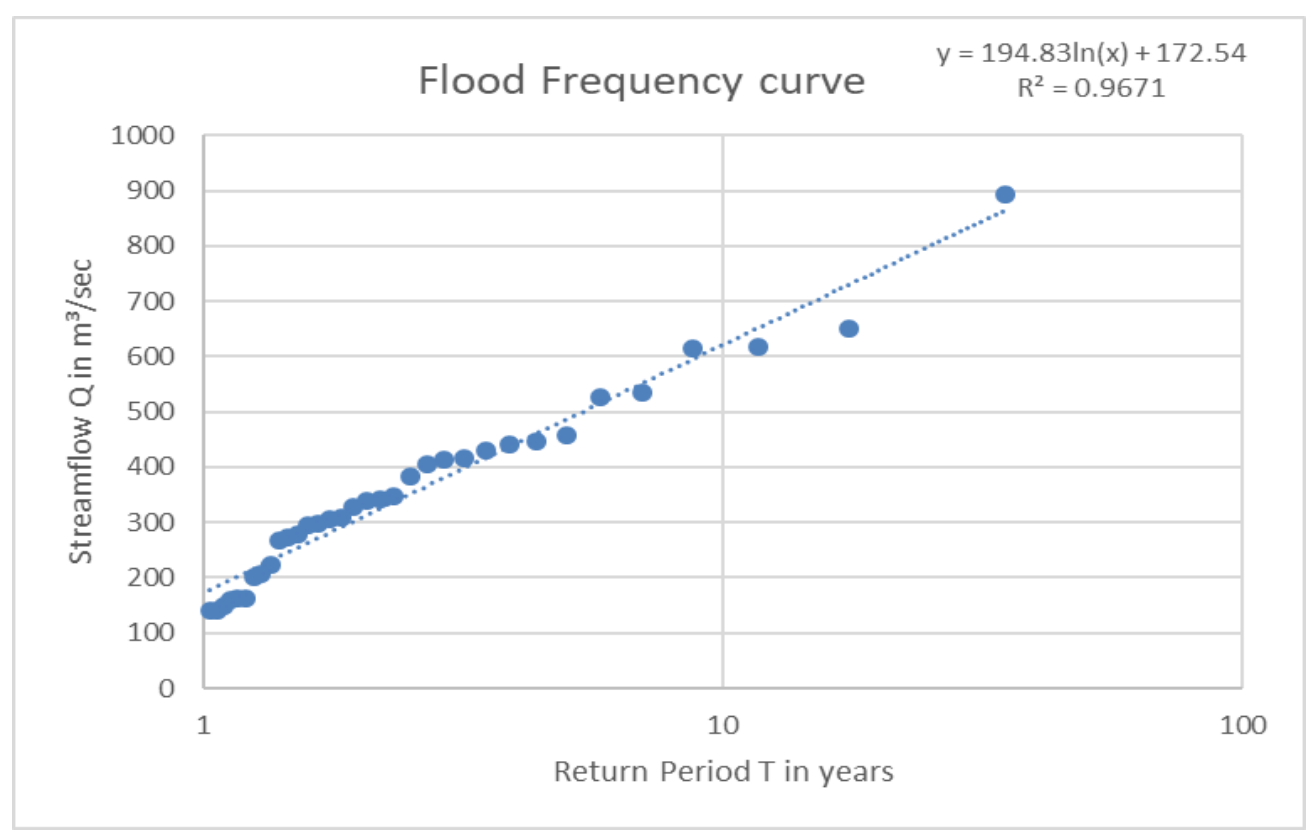

Fig.2 Plot of streamflow versus return period (Frequency curve) 


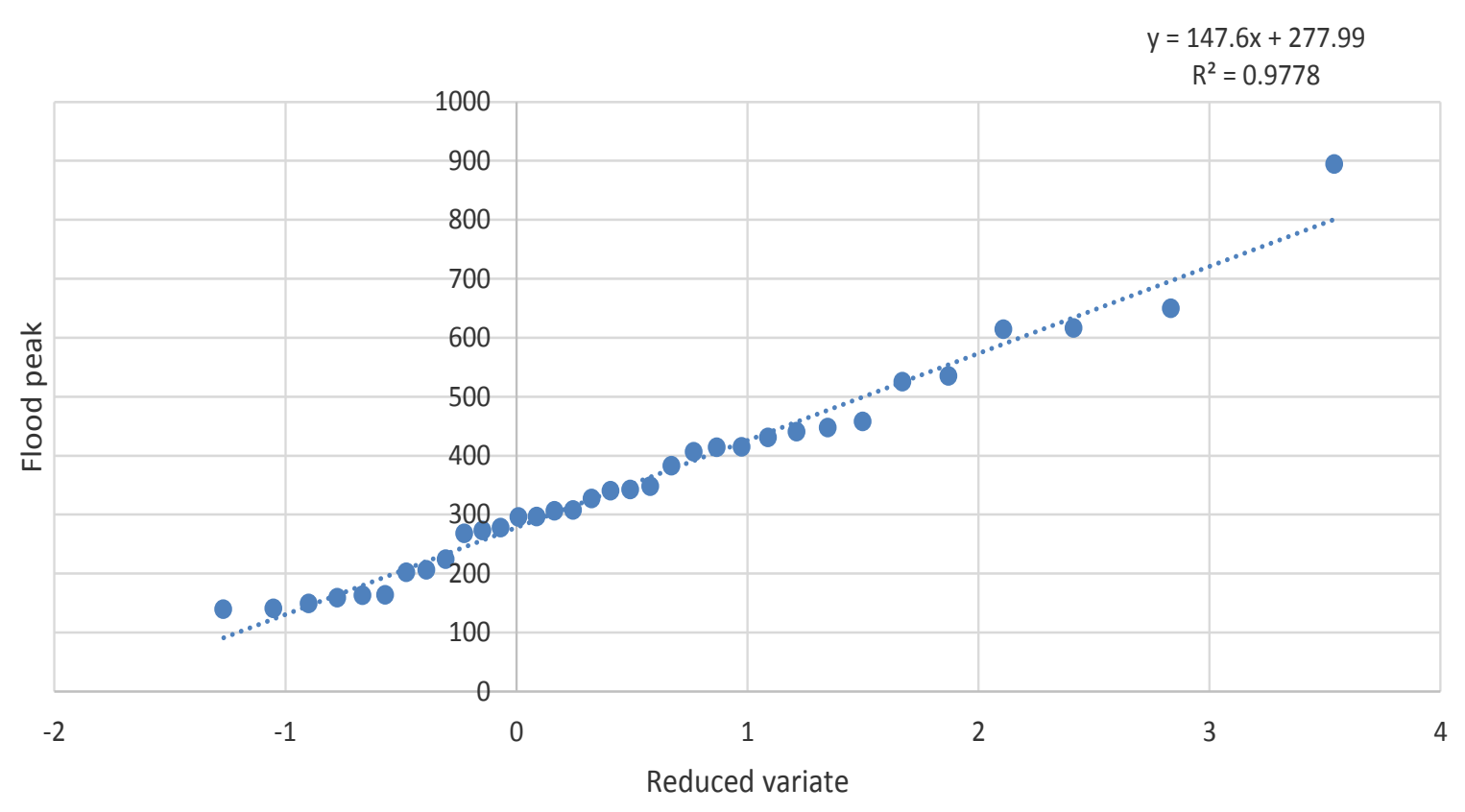

Fig.3 Plot of reduced variate versus peak flood

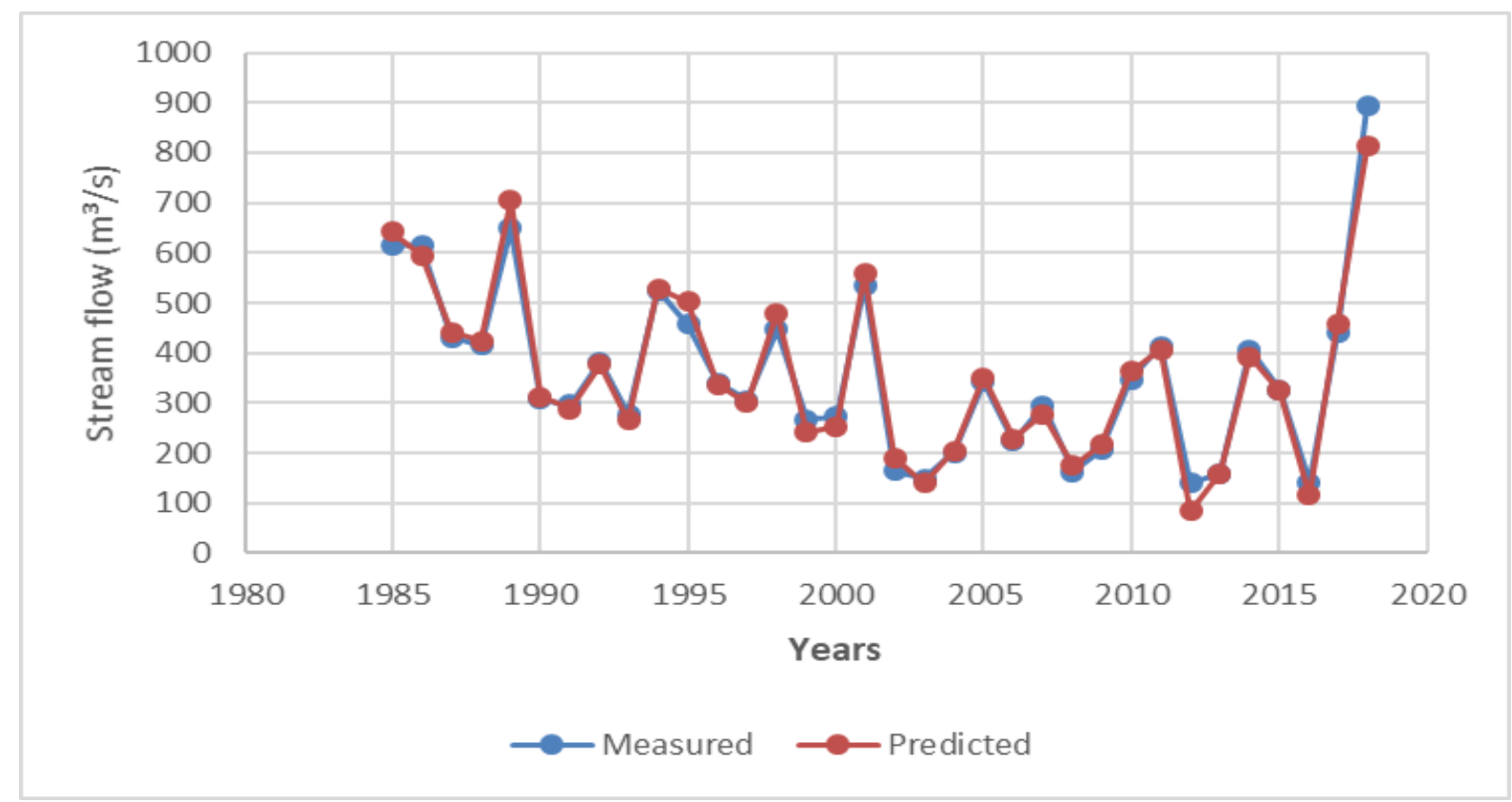

Fig.4 Plot of measured and predicted streamflow values

From the Gumbel's distribution, the expected estimated discharges for return periods of $2 \mathrm{yrs}, 10 \mathrm{yrs}, 50 \mathrm{yrs}$ and $100 \mathrm{yrs}$ were obtained as $331.41 \mathrm{~m}^{3} / \mathrm{s}, 616.84 \mathrm{~m}^{3} / \mathrm{s}, 867.08 \mathrm{~m}^{3} / \mathrm{s}$ and $972.87 \mathrm{~m}^{3} / \mathrm{s}$ respectively. These values can be adopted as a guide for storm water management in the region during flood. The predicted value and measured value of discharge showed good agreement without much variation as indicated in Fig. 4. Flood frequency analysis was carried out for Pala watershed, which lies in the upstream side of Meenachil River basin. The analysis used peak discharge data of 34 years from 1985- 
2018. From the plot of the reduced variate versus peak flood, the trend line equation gives $\mathrm{R}^{2}$ value of 0.9778 . This showed that the pattern of the scatter is narrow and therefore Gumbel's distribution method is suitable for predicting expected discharge in the river. The frequency analysis also showed good capability of the Gumbel distribution to predict river flood magnitudes occurring in different return period.

There were no significant differences between the predicted and measured discharge values. Hence, the model can be reliably applied to predict the occurrence of floods in the catchment. This mathematical relation can also be considered for several extreme event distributions in the region where emergency evacuation of people could be done. This type of flood prediction can also be utilized in the designing of important hydraulic structures in the river reach.

\section{References}

Beard, L.R. 1943. Statistical analysis in hydrology. Trans. Amer. Soc. Civil. Eng. 108, 1110-1160.

Celine, G., Jayakumar, K.V. and James, E.J. 2011. Changes in streamflow regime as indicator of upstream urbanization in a humid tropical river basin. Meteorol. Appl. 19, 334-345.

Chow, V. T. 1964. Handbook of Applied Hydrology. McGraw-Hill, New York, USA.

Chow, V. T., Maidment, D.R. and Mays, L.W. 1988. Appl. Hydrol. McGrawHill, New York, U.S.A.
Haan, C.T. 1977. Statistical Methods in Hydrology. Iowa State University Press, Iowa.

Mujere, N. 2011. Flood Frequency Analysis Using the Gumbel Distribution. Int. J. Comput. Sci. Eng. 3, 2774-2778.

Mujiburrehman, K. 2015. The comparison of Normal, Lognormal, Log Pearson Type III and Gumbel Distribution for Krishna River and evaluation of best distribution. European J. Environ. Ecology. 2, 146-150.

Mukherjee, K.M. 2013. Flood frequency analysis of River Subarnarekha, India, using Gumbel's Extreme Value Distribution. Int. J. Comput. Eng. Res. 3, 12-19.

Nirman, B. 2017. Flood frequency analysis using Gumbel's distribution method: A case study of Lower Mahi Basin, India. J. Water Resour. Ocean Sci. 6, 51-54.

Solomon, O. and Prince, O. 2013. Flood frequency analysis of Osse River using Gumbel's distribution. Civil Environ. Res. 3, 55-59.

Subramanya, K. 2004. Engineering Hydrology. Tata McGraw-Hill Publishing Company Limited, New Delhi, India.

Vincy, M.V., Rajan, B. and Pradeepkumar, A.P. 2012. Geographic information system-based morphometric characterization of sub-watersheds of Meenachil river basin, Kottayam district, Kerala, India. Geocarto International. 27, 661-684.

Zelenhasic, E. 1970. Theoretical Probability Distributions for Flood Peaks. Colorado University Press, Colorado, U.S.A.

\section{How to cite this article:}

Riyola George and Asha Joseph. 2020. Flood Frequency Analysis of a Sub-watershed in Meenachil River Basin Using Gumbels Extreme Value Distribution. Int.J.Curr.Microbiol.App.Sci. 9(06): 3746-3752. doi: https://doi.org/10.20546/ijcmas.2020.906.442 